OPEN ACCESS

Edited by:

Thales Renato Ochotorena De Freitas,

Federal University of Rio Grande do

Sul, Brazil

Reviewed by:

Vera Maria Fonseca Almeida-Val,

National Institute of Amazonian

Research (INPA), Brazil

Gislene Lopes Goncalves,

Federal University of Rio Grande do

Sul, Brazil

${ }^{*}$ Correspondence: Fabio Porto-Foresti fp.foresti@unesp.br

Specialty section:

This article was submitted to Evolutionary and Population Genetics,

a section of the journal

Frontiers in Genetics

Received: 04 June 2021 Accepted: 24 November 2021 Published: 09 December 2021

Citation: Deoclécio da Silva $L M$, do Prado $F D$, Hashimoto DT, Senhorini JA, Foresti F

and Porto-Foresti $F$ (2021) Use of Molecular Genetic Methods to Reduce the Risk of Incorrect Identification of

Fish Strains in Brazilian Aquaculture.

Front. Genet. 12:720736.

doi: $10.3389 /$ fgene.2021.720736

\section{Use of Molecular Genetic Methods to Reduce the Risk of Incorrect Identification of Fish Strains in Brazilian Aquaculture}

\author{
Luana Maria Deoclécio da Silva ${ }^{1}$, Fernanda Dotti do Prado ${ }^{1}$, Diogo Teruo Hashimoto ${ }^{2}$, \\ José Augusto Senhorini ${ }^{3}$, Fausto Foresti ${ }^{4}$ and Fabio Porto-Foresti ${ }^{1 *}$
}

${ }^{1}$ Laboratório de Genética de Peixes, Faculdade de Ciências, Departmento de Ciências Biológicas, Universidade Estadual Paulista, Bauru, Brazil, ${ }^{2}$ Laboratório de Genética em Aquicultura e Conservação, Centro de Aquicultura, Universidade Estadual Paulista, Jaboticabal, Brazil, ${ }^{3}$ Centro Nacional de Pesquisa e Conservação da Biota Aquática Continental (CEPTA-ICMBIO), Pirassununga, Brazil, ${ }^{4}$ Laboratório de Biologia e Genética de Peixes, Instituto de Biociências, Universidade Estadual Paulista, Botucatu, Brazil

The identification of fish species using traditional methods is generally based only on morphological characteristics and these methods are currently under review. This kind of identification of hybrid fishes solely based on their morphologies may be unreliable, especially when the samples include juveniles and post-F1 lineage fishes. Therefore, in the present study, we used molecular markers to accurately identify the fish species of economic interest that are used as materials in the projects developed in research institutions. We evaluated six lots of fishes sampled from different research centers, containing a total of 84 specimens acquired from private fish farms that were considered to be the representatives of pure species. Genetic analyses of all the specimens revealed that, globally, 22 samples (26.2\%) were interspecific hybrids, while $20(90.9 \%)$ samples were surprisingly characterized as post-F1 hybrids. This result confirms that hybrids are sold in markets without adequate labeling and also indicates the lack of proper control of the commercialization and management of stocks and products in fish farms. In addition, we determined that molecular diagnosis was an extremely effective and necessary method to test the reliability of biological materials currently used in scientific research.

Keywords: aquaculture, catFISH, interspecific hybridization, molecular markers, PCR multiplex

\section{INTRODUCTION}

There is an extensive diversity of fish species in the Neotropical region, including Brazil (Vari and Malabarba, 1998; Reis et al., 2016). Despite the presence of a large number of species of economic interest and great potential for their cultivation, consistent data and information on the biology, reproduction, genetics, nutrition, and zootechnical management of these species are still lacking. Many laboratories and research centers are currently working to increase their production chain (see Barroso et al., 2013; Mastrochirico-Filho et al., 2016). These laboratories usually acquire their specimens from private fish farms, which maintain their own stocks of matrices and store their production for sale. However, with the increasing production of interspecific hybrids, the purity of individuals used as study models has become uncertain. 
TABLE 1 | Institution of origin, number of individuals and morphological (phenotypic) identification of all samples analyzed in the current study.

\begin{tabular}{lcl} 
Institution & Number of individuals & \multicolumn{1}{c}{ Morphological identification } \\
\hline A & 49 & Pseudoplatystoma reticulatum (cachara) \\
B & 5 & Pseudoplatystoma reticulatum (cachara) \\
C & 6 & Pseudoplatystoma corruscans (pintado) \\
D & 15 & Pseudoplatystoma corruscans (pintado) \\
E & 9 & Leiarius marmoratus (jundiá)
\end{tabular}

In recent years, the increase in world demand for fish products has led to a significant expansion of the fish farming sector. This advance is associated with the development of several genetic improvement techniques applied to production, including the artificial interspecific hybridization (Bartley et al., 2001; PortoForesti et al., 2011; Porto-Foresti et al., 2013; Hashimoto et al., 2016). In Brazil, the production of native fish and their hybrids has been a great target of agricultural investment, mainly for the catfish species Pseudoplatystoma reticulatum (cachara), Pseudoplatystoma corruscans (pintado) and Leiarius marmoratus (jundiá) (Campos, 2010; Hashimoto et al., 2012a). The national aquaculture sector has increasingly encouraged the large-scale cultivation of these hybrids, as they have more advantageous commercial characteristics when compared to parental species, such as higher growth rates and better meat quality (Crepaldi et al., 2006; Campos, 2010). But, there are some risks associated with the mismanagement of artificial hybrids and their effects on biodiversity conservation and sustainable food production.

The morphological similarity between hybrids and pure species in cultivated stocks can result in mixtures and occasional introgressions, sometimes resulting in serious problems in the maintenance of populations and species (Allendorf and Leary, 1988; Epifanio and Philipp, 2001; Rosenfield et al., 2004). Accidental and uncontrolled hybridization can generate undesirable results in hybrid progenies, such as loss of product quality and reduced growth performance, as well as compromising the genetic integrity of the species (Rahman et al., 2013). According to (Toledo-Filho et al., 1994), the problems could be minimized and even avoided with the knowledge of the genetic profile of the animals involved in the crossings. In this case, effective programs for the characterization and genetic monitoring of stocks must be essential in fish farms, ensuring the correct labeling of parental lines and commercialized products (Toledo-Filho et al., 1994, 1998; Porto-Foresti et al., 2008; Hashimoto et al., 2012a).

Differentes DNA markers have been developed and successfully applied for the identification of fish hybrids species (Hashimoto et al., 2011; Prado et al., 2011; Hashimoto et al., 2012a; Hashimoto et al., 2016; Yabu et al., 2018). Here, we used some of these markers to evaluate the correct identity of catfish species that have been used as material in projects developed in research institutions. Our aim was to verify the purity of the species used in these projects and assess the potential of previous molecular diagnosis to prevent the possible misuse of hybrids as biological material in research.

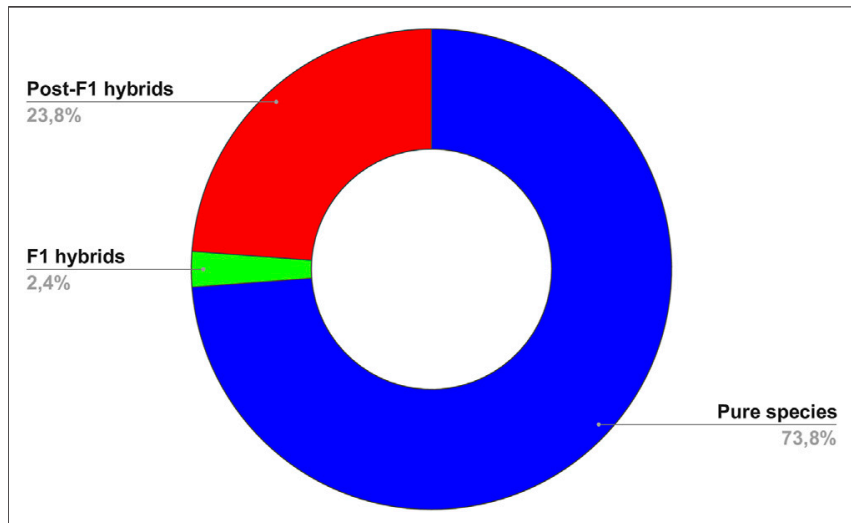

FIGURE 1 | Total percentage of hybrids (F1 and post-F1 generations) among all 84 samples marketed as pure species in private fish farms.

\section{METHODS}

All analyses were conducted at the Fish Genetics Laboratory of the Department of Biological Sciences of the Faculty of Sciences of Bauru or Universidade Estadual Paulista (UNESP), which has expertise in the development of specific genetic markers for Neotropical fish species. We obtained a total of 84 biological samples of $P$. corruscans (pintado), $P$. reticulatum (cachara) and L. marmoratus (jundiá) from five different research centers, hereinafter referred to as institution $A, B, C, D$ and $E$ (Table 1). All samples evaluated in this study were acquired from private Brazilian fish farms, commercially classified by external morphology as pure species. The samples were diagnosed using the multiplex polymerase chain reaction (Multiplex PCR) following the conditions described by Prado et al. (2011) and Hashimoto et al. (2016) for the identification of species belonging to the order Siluriformes. Here we used one mitochondrial marker (16S ribosomal RNA) and three single nuclear genes: RAG2 (nuclear recombination activating gene 2), EF1a (elongation factor 1 -alpha) and glob ( $\beta$-globin). The amplified products were submitted to electrophoresis in a $1.5 \%$ agarose gel and visualized in an ultraviolet (UV) transluminator. According to the genotyping performed through the combine results of nuclear markers, the samples were classified into one of three categories: 1) pure species, if all markers had homozygous genotypes for the initially classified species; 2) F1 hybrid, if all markers had heterozygous genotypes; and 3) post-F1 hybrid presenting combined homozygous and heterozygous genotypes for the nuclear markers. The mitochondrial gene was used to identify the maternal species involved in crosses.

\section{RESULTS AND DISCUSSION}

Our results showed that of the 84 analyzed samples, $73.80 \%$ presented the genetic profile of pure species (confirming their initial classification) and $26.20 \%$ were found as hybrids (mislabeled specimens), with most of them belonging to the post-F1 class $(23.80 \%)$ and $2.40 \%$ of individuals probably 
TABLE 2 | Genetic diagnosis of catfish species from different research center acquired from private fish farms. N: number of individuals sampled; F1 hybrid: first generation interspecific hybrid; Post-F1 hybrid: advanced interspecific hybrid.

\begin{tabular}{|c|c|c|c|}
\hline Samples & Morphological identification (N) & Genotype (N) & Hybrids in the samples (\%) \\
\hline A & Pseudoplatystoma reticulatum (49) & $\begin{array}{l}P \text {. reticulatum }(49) \\
\text { F1 hybrid }(0) \\
\text { Post-F1 hybrid }(0)\end{array}$ & $0 \%$ \\
\hline$B$ & Pseudoplatystoma reticulatum (5) & $\begin{array}{l}P \text {. reticulatum (3) } \\
\text { F1 hybrid (1) } \\
\text { Post-F1 hybrid (1) }\end{array}$ & $40 \%$ \\
\hline C & Pseudoplatystoma corruscans (6) & $\begin{array}{l}\text { P. corruscans }(0) \\
\text { F1 hybrid }(0) \\
\text { Post-F1 hybrid }(6)\end{array}$ & $100 \%$ \\
\hline $\mathrm{D}$ & Pseudoplatystoma corruscans (15) & $\begin{array}{l}\text { P. corruscans (1) } \\
\text { F1 hybrid (1) } \\
\text { Post-F1 hybrid (13) }\end{array}$ & $93.33 \%$ \\
\hline$E$ & Leiarius marmoratus (9) & $\begin{array}{l}\text { L. marmoratus }(9) \\
\text { F1 hybrid }(0) \\
\text { Post-F1 hybrid }(0)\end{array}$ & $0 \%$ \\
\hline
\end{tabular}

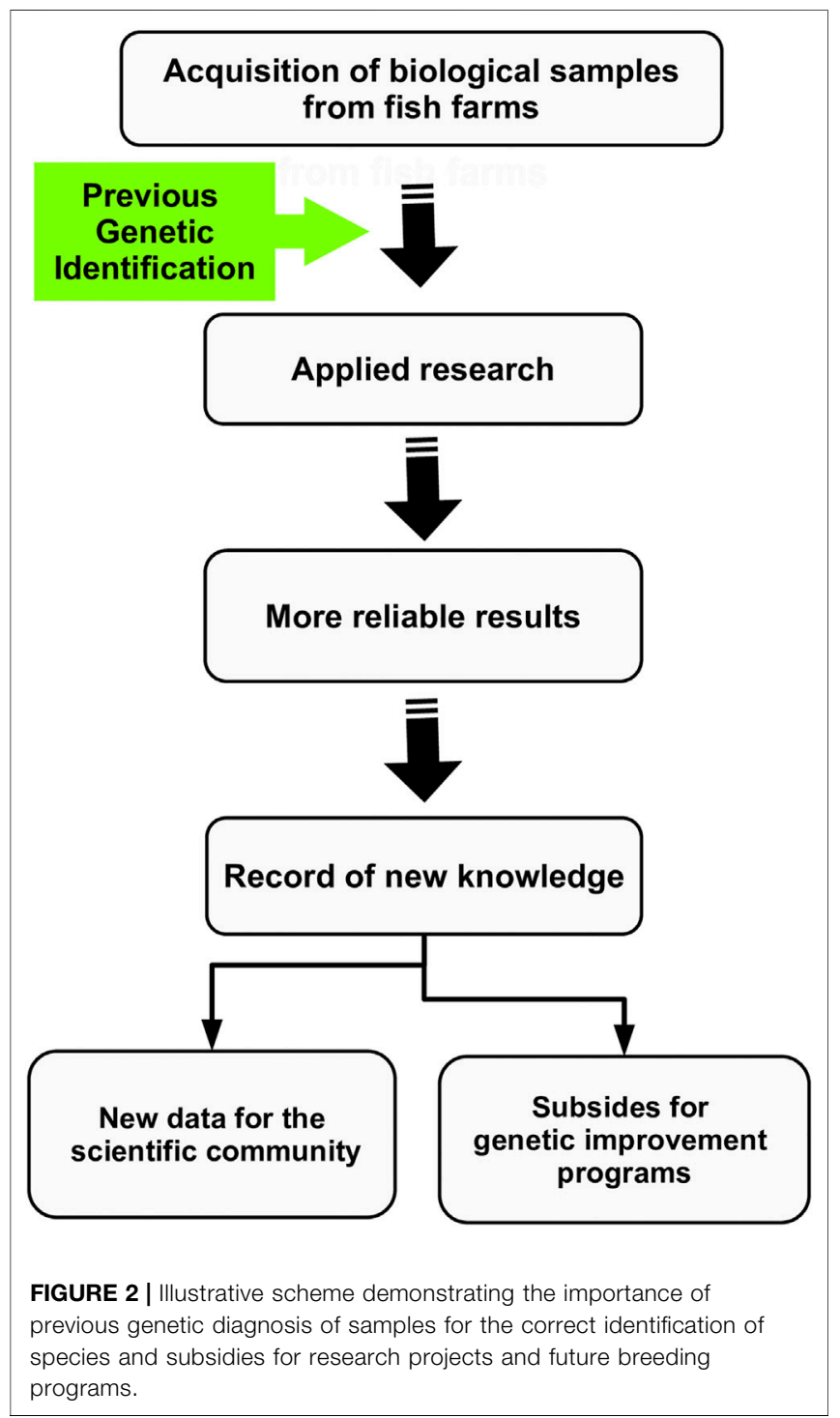

belonging to a F1 hybrid category (Figure 1). All information used in the molecular diagnostic is available in Supplementary Appendix SAI (Supplementary Data). The samples belonging to institutions A and $\mathrm{E}$ were the only ones where we found $100 \%$ purity, where the initial characterization of the species was done correctly. However, the initial identification only by morphology was not accurate for the other samples, where we identified $40 \%$, $100 \%$ and $83.33 \%$ of species as hybrids, referring to institutions B, $\mathrm{C}$ and $\mathrm{D}$, respectively (Table 2). More alarming, among all identified hybrids, $90.90 \%$ were classified as post-F1 generation, indicating the occurrence of backcrosses in the stocks of origin. Misuse of interspecific hybrid fish as pure species in scientific projects can generate false-positive results and lead to the dissemination of unreliable information about the species. Although hybrids may appear externally similar to pure species, they have divergent biological characteristics (ToledoFilho et al., 1994). Furthermore, the zootechnical advantages associated with the "hybrid vigor" may be absent in post-F1 generations, due to the loss of heterosis observed in F1 by introgressive hybridization (Hashimoto et al., 2012b). These factors highlight the need for previous molecular diagnosis in studies involving mainly commercial Neotropical fish species. In addition to obtaining more accurate results, previous genetic identification allows access to new knowledge that can serve as subsides for future genetic improvement programs and commercial production of these species (Figure 2).

The present study demonstrated the effectiveness of molecular markers to assess the reliability of fish farms stocks and products, highlighting the need of correct marking (i.e., genetic identification) for use by the scientific community. Our data confirm that the identification only by external morphology can be imprecise in most cases (institutions B, C and D), reinforcing the importance of previous molecular diagnosis in the characterization of these species. The use of single genes by the Multiplex PCR technique proved to be satisfactory for making this diagnosis, as in addition to producing fast and accurate results, it is a simple and low cost tool. Finally, our 
results confirm the lack of control in the management and commercialization of fish farm products, with the consequent genetic contamination of breeding stocks and the sale of hybrids without proper labeling.

\section{DATA AVAILABILITY STATEMENT}

The raw data supporting the conclusion of this article will be made available by the authors, without undue reservation.

\section{ETHICS STATEMENT}

Ethical review and approval was not required for the animal study because The animals were collected in accordance with Brazilian environmental protection legislation (Collection Permission MMA/ IBAMA/SISBIO-number 3245), and the procedures for the sampling, maintenance and analysis of the fishes were performed in compliance with the Brazilian College of Animal Experimentation (COBEA) and approved (protocol 504) by the Bioscience Institute/ UNESP Ethics Committee on the Use of Animals (CEUA).

\section{AUTHOR CONTRIBUTIONS}

LD-molecular analysis, writing, editing. FP-molecular analysis, revision, editing. $\mathrm{DH}-$ molecular analysis, revision. JS-biologial samples, biological informations, technical support FF-support to interpretate results, writing, revision. FP-Fsupport to interpretate results, writing, revision (coordination of the Laboratory).

\section{REFERENCES}

Allendorf, F. W., and Leary, R. F. (1988). Conservation and Distribution of Genetic Variation in a Polytypic Species, the Cutthroat trout. Conservation Biol. 2, 170-184. doi:10.1111/j.1523-1739.1988.tb00168.x

Aminur Rah, M., Arshad, A., Marimuthu, K., Ara, R., and Amin, S. M. N. (2013). Inter-specific Hybridization and its Potential for Aquaculture of Fin Fishes. Asian J. Anim. Vet. Adv. 8, 139-153. doi:10.3923/ajava.2013.139.153

Barroso, A. S., Silva, L. R., Barros, V. M., Oliveira, A. S., Alves, M. S. S., Varela, E. S., et al. (2013). Implantação Do banco de DNA de peixes na Bacia Do AraguaiaTocantins: aplicações em taxonomia, produção e conservação de recursos genéticos. Revista Universitária Integrada 7, 173-180.

Bartley, D. M., Rana, K., and Immink, A. J. (2000). The Use of Inter-specific Hybrids in Aquaculture and Fisheries. Rev. Fish. Biol. Fish. 10, 325-337. doi:10.1023/A:1016691725361

Campos, J. L. (2010). "O cultivo Do pintado (Pseudoplatystoma corruscans, Spix; Agassiz, 1829), outras espécies Do gênero Pseudoplatystoma e seus híbridos," in Espécies nativas para a piscicultura no Brasil. Editors B. Baldisserotto and L. C. Gomes (Santa Maria: Universidade Federal de Santa Maria), 335-361.

Crepaldi, D. V., Faria, P. M. C., Teixeira, E. A., Ribeiro, L. P., Costa, A. A. P., Melo, D. C., et al. (2006). O Surubim Na Aquacultura Do Brasil. Rev. Bras. Reprod. Anim. 30, 150-158.

do Prado, F. D., Hashimoto, D. T., Mendonça, F. F., Senhorini, J. A., Foresti, F., and Porto-Foresti, F. (2011). Molecular Identification of Hybrids between Neotropical Catfish Species Pseudoplatystoma Corruscans and Pseudoplatystoma Reticulatum. Aquac. Res. 42, 1890-1894. doi:10.1111/ j.1365-2109.2010.02777.x

\section{FUNDING}

We would also like to thank the National Council for Scientific and Technological Development or Conselho Nacional de Desenvolvimento Científico e Tecnológico (CNPq), the São Paulo Research Foundation or Fundação de Amparo à Pesquisa do Estado de São Paulo (FAPESP), and Coordination for the Improvement of Higher Education Personnel or Coordenação de Aperfeiçoamento de Pessoal de Nível Superior (CAPES) for their financial support.

\section{ACKNOWLEDGMENTS}

The authors would like to thank the São Paulo State University (UNESP) and the Fish Genetics Laboratory or Laboratório de Genética de Peixes (LAGENPE) for providing basic support for this research. We would also like to acknowledge the Brazilian Institute of Environment and Renewable Natural Resources or Instituto Brasileiro do Meio Ambiente e dos Recursos Naturais Renováveis (IBAMA), which kindly provided the materials for this study and assisted in their collection.

\section{SUPPLEMENTARY MATERIAL}

The Supplementary Material for this article can be found online at: https://www.frontiersin.org/articles/10.3389/fgene.2021.720736/ full\#supplementary-material

Epifanio, J., and Philipp, D. (2000). Simulating the Extinction of Parental Lineages from Introgressive Hybridization: the Effects of Fitness, Initial Proportions of Parental Taxa, and Mate Choice. Rev. Fish. Biol. Fish. 10, 339-354. doi:10.1023/ A:1016673331459

Hashimoto, D. T., Mendonça, F. F., Senhorini, J. A., de Oliveira, C., Foresti, F., and Porto-Foresti, F. (2011). Molecular Diagnostic Methods for Identifying Serrasalmid Fish (Pacu, Pirapitinga, and Tambaqui) and Their Hybrids in the Brazilian Aquaculture Industry. Aquaculture 321, 49-53. doi:10.1016/j.aquaculture.2011.08.018

Hashimoto, D. T., Prado, F. D. D., Senhorini, J. A., Foresti, F., and Porto-Foresti, F. (2012b). Detection of post-F1 Fish Hybrids in Broodstock Using Molecular Markers: Approaches for Genetic Management in Aquaculture. Aquac. Res. 44, 876-884. doi:10.1111/j.1365-2109.2012.03092.x

Hashimoto, D. T., Prado, F. D., Foresti, F., Porto-Foresti, F., and Porto-Foresti, F. (2016). Molecular Identification of Intergenus Crosses Involving Catfish Hybrids: Risks for Aquaculture Production. Neotrop. Ichthyol. 14, 1-8. doi:10.1590/1982-0224-20150139

Hashimoto, D. T., Senhorini, J. A., Foresti, F., and Porto-Foresti, F. (2012a). Interspecific Fish Hybrids in Brazil: Management of Genetic Resources for Sustainable Use. Rev. Aquac. 4, 108-118. doi:10.1111/j.17535131.2012.01067.x

Mastrochirico-Filho, V. A., Hata, M. E., Sato, L. S., Jorge, P. H., Foresti, F., Rodriguez, M. V., et al. (2016). SNP Discovery from Liver Transcriptome in the Fish Piaractus Mesopotamicus. Conservation Genet. Resour. 8, 109-114. doi:10.1007/s12686-016-0521-3

Porto-Foresti, F., Hashimoto, D. T., Alves, A. L., Almeida, R. B. C., Senhorini, J. A., Bortolozzi, J., et al. (2008). Cytogenetic Markers as Diagnoses in the Identification of the Hybrid between Piauçu (Leporinus Macrocephalus) and 
Piapara (Leporinus elongatus). Genet. Mol. Biol. 31, 195-202. doi:10.1590/ S1415-47572008000200005

Porto-Foresti, F., Hashimoto, D. T., Prado, F. D., Senhorini, J. A., and Foresti, F. (2013). Genetic Markers for the Identification of Hybrids Among Catfish Species of the Family Pimelodidae. J. Appl. Ichthyol. 29, 643-647. doi:10.1111/jai.12092

Porto-Foresti, F., Hashimoto, D. T., Prado, F. D., Senhorini, J. A., and Foresti, F. (2011). Hibridização Interespecífica Em Peixes. Panorama da aquicultura 21, $28-33$

Reis, R. E., Albert, J. S., Di Dario, F., Mincarone, M. M., Petry, P., and Rocha, L. A. (2016). Fish Biodiversity and Conservation in South America. J. Fish. Biol. 89 (1), 12-47. doi:10.1111/jfb.13016

Rhymer, J. M., and Simberloff, D. (1996). Extinction by Hybridization and Introgression. Annu. Rev. Ecol. Syst. 27, 83-109. doi:10.1146/ annurev.ecolsys.27.1.83

Rosenfield, J. A., Nolasco, S., Lindauer, S., Sandoval, C., and Kodric-Brown, A. (2004). The Role of Hybrid Vigor in the Replacement of pecos Pupfish by its Hybrids with Sheepshead Minnow. Conserv Biol. 18, 1589-1598. doi:10.1111/j.1523-1739.2004.00356.x

Toledo-Filho, S. A., Almeida-Toledo, L. F., Foresti, F., Bernardino, G., and Calcagnotto, D. (1994). Monitoramento e conservação genética em projeto de hibridação entre pacu e tambaqui - cadernos de Ictiogenética 2. São Paulo: CCS/USP.

Toledo-Filho, S. A., Almeida-Toledo, L. F., Foresti, F., Bernardino, G., and Calcagnotto, D. (1998). Programas genéticos de seleção, hibridação $e$ endocruzamentos aplicados à piscicultura - cadernos de Ictiogenética 4. São Paulo: CCS/USP.
Vari, R. P., and Malabarba, L. R. (1998). "Neotropical Ichthyology: An Overview," in Phylogeny and Classification of Neotropical Fishes. Editors L. R. R. E. Malabarba, R. P. Reis, R. P. Vari, and Z. M. S. Lucena (RS: Edipucrs: Porto Alegre), 1-12.

Yabu, M. H. S., Vidotto-Magnoni, A. P., Casimiro, A. C. R., Garcia, D. A. Z., Costa, A. D. A., Prado, F. D. D., et al. (2018). First Record of Non-native Hybrid catfishPseudoplatystoma Reticulatum $\times$ Leiarius Marmoratusin the Upper Paraná River basin, Brazil. J. Fish. Biol. 92, 261-267. doi:10.1111/jfb.13505

Conflict of Interest: The authors declare that the research was conducted in the absence of any commercial or financial relationships that could be construed as a potential conflict of interest.

Publisher's Note: All claims expressed in this article are solely those of the authors and do not necessarily represent those of their affiliated organizations, or those of the publisher, the editors and the reviewers. Any product that may be evaluated in this article, or claim that may be made by its manufacturer, is not guaranteed or endorsed by the publisher.

Copyright () 2021 Deoclécio da Silva, do Prado, Hashimoto, Senhorini, Foresti and Porto-Foresti. This is an open-access article distributed under the terms of the Creative Commons Attribution License (CC BY). The use, distribution or reproduction in other forums is permitted, provided the original author(s) and the copyright owner(s) are credited and that the original publication in this journal is cited, in accordance with accepted academic practice. No use, distribution or reproduction is permitted which does not comply with these terms. 